\title{
The Influence of Job Insecurity and Organizational Commitment on Nurses Performance in Installations in Public Hospitals in Makassar City
}

Nila Praptiningtyas ${ }^{1}$, Alimin Maidin ${ }^{1,2}$, Syamsuddin ${ }^{2}$

${ }^{1}$ Hospital ManagementDepartment, Faculty of Public Health, Hasanuddin University, Indonesia

${ }^{2}$ Accounting Department, Faculty of Economics and Business, Hasanuddin University, Indonesia

*Corresponding Author: Nila Praptiningtyas

Email: nilaino89@gmail.com

Received: April 5, 2021

Revised: May 7, 2021

Accepted: May 18, 2021

\section{Abstract}

Performance is critical for the current and future organizational environment, and performance appraisal methods that have focused exclusively on financial performance have limitations; therefore, effective performance measurement should be capable of translating an organization's mission, vision, and strategy into operational objectives and performance measures. financial as well as non-financial success indicators. The purpose of this research is to examine the influence of job insecurity and organizational commitment on the performance of nurses at Makassar City Hospital's inpatient unit. This is a quantitative study that combines an observational design with a cross sectional study design. The sample for this research consisted of 84 nurses working in the inpatient unit of Makassar City Hospital. The findings indicated that job insecurity characteristics and organizational commitment had an influence on the performance of nurses at the Makassar City Hospital's Inpatient Installation. The bivariate analysis results indicate that the job insecurity variable has an effect on the performance of nurses in Makassar City Hospital with a value of $p=0.0000 .05$, that the job insecurity variable has an effect on the organizational commitment of nurses in Makassar City Hospital with a value of $p=0.0000 .05$, and that the variable organizational commitment has an effect on the performance of nurses in Makassar City Hospital with a value of $p=0.0000 .05$. It is recommended that the hospital management pay attention to employees, better facilities and benefits, adequate working hours and rest.

Keywords: Job Insecurity, Organizational Commitment, Performance, Nurses, Hospitals

\section{Introduction}

The era of world globalization is marked by an increasingly rapid development in all fields of business activity. The globalization of the 90s that swept the world has influenced the development of the Indonesian economy. The emerging globalization is global competition, global business, and global company. Competition in the business world is very tight and exposes organizations to public services that can be highly competitive and efficient. Likewise, hospitals as institutions engaged in health services must be able to provide quality and quality services, both in terms of service, care and also provide good facilities for patients (Hadijah, 2016). 
To provide a quality hospital, facilities and infrastructure are needed in sufficient quantity and quality. For this reason, it is necessary to be supported by competent and professional human resources. The concept of quality management (quality control) is an effort to increase the morale of human resources which aims to improve hospital performance and services. This effort can be achieved if it is supported by quality human resource management, so as to improve performance in accordance with the objectives (Iman et al, 2017).

Performance is critical for the current and future organizational environment, and performance appraisal methods that have focused exclusively on financial performance have limitations; therefore, effective performance measurement should be capable of translating an organization's mission, vision, and strategy into operational objectives and performance measures. financial as well as non-financial performance indicators (Gaspersz, 2003). Performance reflects a deep enjoyment of the work being done so that work can be completed faster and better results can be achieved.

In organizations, workers who perceive job insecurity tend to have low organizational commitment which can then result in a decrease in performance or work performance and increase their intention to leave the organization (Sverke et al., 2002). An even more detrimental thing that can happen to the organization, especially if the workers who decide to quit are workers who are of good quality. This job insecurity condition arises because of the many types of jobs that are temporary in nature. The increasing number of types of work with temporary or non-permanent time duration causes more employees to experience job insecurity.

Job Insecurity is also an employee's assessment of his job which causes him to feel that his job is threatened and feel helpless to do anything about the situation. This can be detected early, namely by conducting regular checks on employees, for example by gradually evaluating employee performance, or it can also be seen from the employee absentee level.

Along with achieving effective and efficient employee performance, management must garner employee commitment to the organization, as employee commitment to the organization entails identification with organizational goals, the ability to channel all power for the benefit of the organization, and an interest in remaining a part of the organization. Employee commitment to the company instills loyalty in workers and motivates them to perform effectively for the company's benefit (Yuwalliatin, 2006).

The commitment formed to employees to their organization is very important in the integrity and progress of an organization. According to Robbins, Stephen P., and Judge (2013), organizational commitment is a state in which workers support a specific firm and its aims and wish to remain a part of that firm.

The results of the performance evaluation of nurses in the hospital were measured using nursing care standards based on the standards of the Indonesian National Nurses Association (PPNI) in 2010, the achievement of the performance of nurses at Makassar City Hospital in 2017 was $75.70 \%$ with details of nursing care, namely dimensions of nursing assessments, nursing diagnoses, planning, nursing actions, evaluations, and nursing records from the PPNI (Indonesian National Nurses Association) standard, namely $100 \%$. 
Previous interviews with the HR department were also obtained, where some nurses seemed to only work according to their job, lack of motivation to work and arrive late, lack of sense of belonging, loss of awareness when leaving the organization and decreased level of interest in the organization will affect employee loyalty to Makassar City Hospital. . Apart from organizational commitment, job insecurity is also an important factor in relation to employee performance. Security in this context does not mean only safety from work accidents, but a sense of security from the threat of losing your job (Haerani, 2014). Likewise with Makassar City Hospital, which still uses a temporary contract work system. The increasing number of types of work with temporary or non-permanent time duration causes more employees to experience job insecurity.

Based on the results of interviews with several nurses with honorary or contract status, they were worried that the work contract could not be extended at any time. The existence of concerns about the existence of jobs in the future indicates the high quantitative job insecurity. Another contract employee said he felt threatened and had perceptions about the deteriorating quality of work, working conditions and reduced future salary increases. Contract employees are employees who are seconded to complete routine hospital jobs and there is no guarantee of their continuity of employment. In this case, the continuity of the contract employee's tenure is determined by their work performance. If the work performance is good, the work contract will be extended. Contract employees will also experience job insecurity psychologically. Where, Not only is job insecurity a result of the danger of job loss, but it is also a result of the loss of the job dimension (Ashford et al., 1989; Greenhalgh \& Rosenblatt, 1984; Rosenblatt \& Ruvio, 1996). Chen (2006) asserts that job uncertainty has a greater influence on persons with short or temporary work tenure than on those with permanent employment status.

The low level of performance achieved actually illustrates that the quality of service from the hospital is low. The consequence is that the hospital management concerned should improve the quality of service to patients, especially for those who are currently hospitalized. In relation to the need to improve health services, one of which is the development of human resources, namely employees in the hospital.

\section{Methods}

This is a quantitative study that employs an observational design with a Cross Sectional Study methodology. This study was carried out in the Makassar City Hospital. The population of this research consisted of all nurses who provided services and served at the Makassar City Hospital's Inpatient Installation, which totaled 84 individuals. The sample size for this research is 84 respondents utilizing complete sampling. The instrument used in data collection was a questionnaire, regarding the independent variables in the form of job insecurity and organizational commitment, while the dependent variable was the nurse's performance. Univariate analysis was conducted to obtain an overview of the research problem by describing each variable used in the study and the characteristics of the respondent. Univariate analysis consisted of descriptive analysis of the characteristics of the respondents, descriptive analysis of the research variables and analysis of the crosstabulation between the characteristics of the respondents and the research variables. Bivariate analysis was carried out to see the relationship between two variables, namely between the independent variable and the dependent variable. DOI: https://doi.org/10.48173/jdmps.v2i2.101

Copyright@2021, Journal Dimensie Management and Public Sector, Underthelicense CC BY-SA 4.0 |65 
The statistical test used was the Pearson correlation test.

\section{Results and Discussion}

Table 1. Characteristics of Nurses Makassar City Hospital

\begin{tabular}{|l|c|c|}
\hline \multirow{2}{*}{ characteristic } & \multicolumn{2}{c|}{ Research Samples } \\
\cline { 2 - 3 } & \multicolumn{2}{c|}{$\mathrm{n}$} \\
\hline age & 25 & 29.8 \\
\hline 20-35 Years Old & 42 & 50.0 \\
\hline 30-45 Years Old & 17 & 20.2 \\
\hline$>45$ Years & 84 & 100.0 \\
\hline sum & \multicolumn{2}{|c|}{} \\
\hline gender & 16 & 19,0 \\
\hline man & 68 & 81.0 \\
\hline woman & 84 & 100.0 \\
\hline sum & \multicolumn{2}{|c|}{} \\
\hline Length of Work & 19 & 22.6 \\
\hline 3-5 Years & 45 & 53.6 \\
\hline 6-8 Years Old & 20 & 23.8 \\
\hline$>8$ Years & 84 & 100 \\
\hline sum & 47 & 56.0 \\
\hline Last Education & 37 & 44.0 \\
\hline Bachelor of Nurse & 84 & 100.0 \\
\hline Ners & & \\
\hline sum & & \\
\hline
\end{tabular}

Source: Primary Data

Table 1 shows the frequency distribution based on the characteristics of the sample at the research location, most of the respondents at Makassar City Hospital were at the age level of 3045 years as many as 42 respondents (50\%). In terms of gender, most of the respondents were female, namely 68 respondents (81\%). Judging from the length of work, most of the respondents with $6-8$ years of work were mostly 45 respondents (53.6\%). In terms of education, most of the respondents were undergraduate nursing students, namely as many as 47 respondents (57\%).

Table 2. Variable Research Makassar City Hospital

\begin{tabular}{|l|c|c|}
\hline \multirow{2}{*}{ variable } & \multicolumn{2}{c|}{ Research Samples } \\
\cline { 2 - 3 } & $\mathrm{n}$ & $\%$ \\
\hline Job Insecurity & 43 & 51.2 \\
\hline tall & 41 & 48.8 \\
\hline low & 84 & 100.0 \\
\hline sum & 39 & 46.4 \\
\hline Organizational Commitment & 45 & 53.6 \\
\hline tall & & \\
\hline low &
\end{tabular}




\begin{tabular}{|l|c|c|} 
sum & 84 & 100.0 \\
\hline Nurse Performance \\
\hline tall & 40 & 47.6 \\
\hline low & 44 & 52.4 \\
\hline sum & 84 & 100.0 \\
\hline
\end{tabular}

Source: Primary Data

Table 2 explains the percentage of respondents' assessment of the research variables. The results of most respondents stated that they were in the high insecurity job category in Makassar City Hospital at $51.2 \%$, in the low organizational commitment category at Makassar City Hospital by $53.6 \%$, in the low low performance nurse category at Makassar City Hospital by 52.4\%.

\section{The Effect of Job Insecurity on Organizational Commitment}

Table 3. Effect of Indepent Variables with Dependent Variables of Makassar City Hospital

\begin{tabular}{|c|r|r|r|}
\hline$R$ & $\begin{array}{c}R \\
\text { Square }\end{array}$ & $\begin{array}{c}\text { Adjusted } R \\
\text { Square }\end{array}$ & $\begin{array}{c}\text { Std. Error of } \\
\text { the Estimate }\end{array}$ \\
\hline $.468 \mathrm{a}$ & .219 & .209 & 8.108 \\
\hline
\end{tabular}

\begin{tabular}{|c|c|c|c|c|c|}
\hline Model & $\begin{array}{l}\text { Sum of } \\
\text { Squares }\end{array}$ & Df & $\begin{array}{l}\text { Mean } \\
\text { Square }\end{array}$ & $F$ & Sig. \\
\hline Regression & 1510.312 & 1 & 1510.312 & 22.975 & $.000 b$ \\
\hline Residual & 5390.355 & 82 & 65.736 & & \\
\hline Total & 6900.667 & 83 & & & \\
\hline
\end{tabular}

\begin{tabular}{|c|c|c|c|c|c|}
\hline \multirow[t]{2}{*}{ Model } & \multicolumn{2}{|c|}{$\begin{array}{l}\text { Unstandardized } \\
\text { Coefficients }\end{array}$} & \multirow{2}{*}{$\begin{array}{c}\text { Standardize } \\
\text { d } \\
\text { Coefficients } \\
\text { Beta }\end{array}$} & \multirow[t]{2}{*}{$\mathrm{T}$} & \multirow[t]{2}{*}{ Sig. } \\
\hline & B & Std. Error & & & \\
\hline (Constant) & 40.839 & 5.255 & & 7.772 & .000 \\
\hline $\begin{array}{l}\text { Job } \\
\text { Insecurity }\end{array}$ & .624 & .130 & .468 & 4.793 & .000 \\
\hline
\end{tabular}

The Effect of Job Insecurity on Performance

\begin{tabular}{|c|r|r|c|}
\hline$R$ & $\begin{array}{c}R \\
\text { Square }\end{array}$ & $\begin{array}{c}\text { Adjusted } R \\
\text { Square }\end{array}$ & $\begin{array}{c}\text { Std. Error } \\
\text { of the } \\
\text { Estimate }\end{array}$ \\
\hline $.609 a$ & .371 & .363 & 12.235 \\
\hline
\end{tabular}




\begin{tabular}{|l|l|r|r|r|r|r|}
\hline \multicolumn{2}{|l|}{ Model } & $\begin{array}{c}\text { Sum of } \\
\text { Squares }\end{array}$ & df & Mean Square & F & Sig. \\
\hline & Regression & 7235.616 & 1 & 7235.616 & 48.334 & $.000 \mathrm{~b}$ \\
\hline Residual & 12275.372 & 82 & 149.700 & & \\
\hline & Total & 19510.988 & 83 & & & \\
\hline
\end{tabular}

\begin{tabular}{|c|c|c|c|c|c|}
\hline \multirow[t]{2}{*}{ Model } & \multicolumn{2}{|c|}{$\begin{array}{l}\text { Unstandardized } \\
\text { Coefficients }\end{array}$} & \multirow{2}{*}{$\begin{array}{c}\text { Standardize } \\
\mathrm{d} \\
\text { Coefficients } \\
\text { Beta }\end{array}$} & \multirow[t]{2}{*}{$\mathrm{T}$} & \multirow[t]{2}{*}{ Sig. } \\
\hline & B & Std. Error & & & \\
\hline (Constant) & 44.002 & 7.930 & & 5.549 & .000 \\
\hline Job Insecurity & 1.365 & .196 & .609 & 6.952 & .000 \\
\hline
\end{tabular}

The Impact of Organizational Commitment on Performance

\begin{tabular}{|c|r|r|c|}
\hline $\mathrm{R}$ & $\begin{array}{c}\mathrm{R} \\
\text { Square }\end{array}$ & $\begin{array}{c}\text { Adjusted } \mathrm{R} \\
\text { Square }\end{array}$ & $\begin{array}{c}\text { Std. Error } \\
\text { of the } \\
\text { Estimate }\end{array}$ \\
\hline $.478 \mathrm{a}$ & .229 & .219 & 13.547 \\
\hline
\end{tabular}

\begin{tabular}{|l|l|r|r|r|r|l|}
\hline \multicolumn{2}{|l|}{ Model } & \multicolumn{1}{c|}{$\begin{array}{c}\text { Sum of } \\
\text { Squares }\end{array}$} & df & $\begin{array}{c}\text { Mean } \\
\text { Square }\end{array}$ & $F$ & Sig. \\
\hline & Regression & 4463.163 & 1 & 4463.163 & 24.321 & $.000 b$ \\
\hline & Residual & 15047.825 & 82 & 183.510 & & \\
\hline & Total & 19510.988 & 83 & & & \\
\hline
\end{tabular}

\begin{tabular}{|c|c|c|c|c|c|}
\hline \multirow[t]{2}{*}{ Model } & \multicolumn{2}{|c|}{$\begin{array}{l}\text { Unstandardized } \\
\text { Coefficients }\end{array}$} & \multirow{2}{*}{$\begin{array}{c}\text { Standardize } \\
\mathrm{d} \\
\text { Coefficients } \\
\text { Beta }\end{array}$} & \multirow[t]{2}{*}{$\mathrm{T}$} & \multirow[t]{2}{*}{ Sig. } \\
\hline & B & Std. Error & & & \\
\hline (Constant) & 45.535 & 10.810 & & 4.212 & .000 \\
\hline $\begin{array}{l}\text { Komitmen } \\
\text { organisasi }\end{array}$ & .804 & .163 & .478 & 4.932 & .000 \\
\hline
\end{tabular}

The link between the independent and dependent variables is shown in Table 3. The findings of the research indicate that job instability and organizational commitment have an effect on the performance of nurses at the Makassar City Hospital's inpatient installation. The bivariate 
analysis results indicate that the job insecurity variable has an effect on the performance of nurses in Makassar City Hospital with a value of $p=0.0000 .05$, that the job insecurity variable has an effect on the organizational commitment of nurses in Makassar City Hospital with a value of $p=0.0000 .05$, and that the organizational commitment variable has an effect on the performance of nurses in Makassar City Hospital with a value of $p=0.0000 .05$.

The research hypothesis $1(\mathrm{H} 1)$ asserts that job uncertainty has a direct influence on nurse performance. According to the results of the statistical research, job instability has a direct influence on the performance of nurses at Makassar City Hospital. A significant effect is also indicated by a significance value of 0.000 so that in this case the research hypothesis $1(\mathrm{H} 1)$ is accepted.

The results of the study based on the job insecurity variable with a high category in Makassar City Hospital were 51.2\%. This shows that the increase in employee job security, the lower the employee's performance. Conversely, the lower the employee's job insecurity, the more the employee's performance will increase.

Job insecurity is seen as the precursor to job loss and arises as a result of organizational change (Bosman et al., 2005). Job insecurity is an inability to sustain desired continuity in hazardous work circumstances (Suciati et al., 2015). Kang et al. (2012) define Job Insecurity as the anxiety experienced by workers when confronted with undesirable working circumstances. Work insecurity may be a result of workers' doubt about the job characteristics they perceive. The desired job characteristic is a change in the nature of the job, career concerns, a decrease in working hours, or, most importantly, job loss (Silla et al., 2010). According to Sverke et al. (2002), job insecurity has a short-term effect on performance, organizational commitment and confidence in leaders, job satisfaction, and job participation, but has a long-term effect on physical health, mental health, work performance, and desire to shift employment (turnover).

This is supported by research by Gaunt \& Benjamin (2007) which states that men are more likely to experience job insecurity in their jobs than women. In some age ranges, the ages of 18-40 who are included in early adulthood are the majority of respondents. This is supported by the results of research conducted by Mauno et al. (2005), namely that job insecurity tends to be more susceptible to young employees than older employees.

The second research hypothesis $(\mathrm{H} 2)$ asserts that job uncertainty has a direct influence on organizational commitment. According to the statistical study conducted, job uncertainty has a direct influence on nurses' organizational commitment at Makassar City Hospital. A significance score of 0.000 also indicates a substantial impact, indicating that the study hypothesis $2(\mathrm{H} 2)$ is adopted in this circumstance.

The results of the study were based on the organizational commitment variable in Makassar City Hospital which was found in the low category of $53.6 \%$. This shows the low commitment of nurse organizations because nurses feel that their current workplace does not have a definite future, is less able to face threats that can arise from around me.

Many organizations claim that their members are the most important assets and agents for the success of the organization (Gasic \& Pagon, 2004). Organizational effectiveness will be achieved 
if all members have a high commitment to achieving organizational goals. Increased commitment from each member of the organization will be possible, if the organization is able to meet the needs and goals of its members (Khan \& Zafar, 2013). Organizational members who have a higher level of commitment will be more enthusiastic and motivated to carry out their duties or jobs.

The negative consequence demonstrates that as job uncertainty increases, organizational commitment decreases. This is consistent with Moshoeu and Geldenhuys's (2015) study, which indicates that workers who fear losing their employment would increase their participation in the firm in order to remain employed.

The findings of this study corroborate those of Setiawan \& Hadiyanto (2008), Tarigan (2012), and Klandermans et al. (2010), who found a negative correlation between job insecurity and organizational commitment, implying that the greater the job insecurity, the lower the organizational commitment. The existence of this low commitment may be caused by inconvenience at work, or employee job insecurity. The characteristics of job insecurity are employees who feel uncomfortable when working, feel helpless in dealing with these conditions.

The third research hypothesis $(\mathrm{H} 3)$ asserts that organizational commitment has a direct influence on nurse performance. According to the results of the statistical research, organizational dedication has a direct influence on the performance of nurses at Makassar City Hospital. A significant effect is also indicated by a significance value of 0.012 so that in this case the research hypothesis $2(\mathrm{H} 2)$ is accepted.

The results of the study based on the variable organizational commitment with the low category in Makassar City Hospital were 53.6\%. This shows that the lower the sense of commitment to the organization that is felt by employees, the less good the employee's performance will be.

Sopiah (2008) describes organizational commitment as an attitude toward employee loyalty to the organization. It is a continuous process by which organizational members demonstrate their care for the organization, which contributes to the organization's success and welfare. Minner identifies four aspects that affect organizational commitment in Sopiah (2008): personal traits, job qualities, structural features, and work experience. Sopiah (2008) organizational commitment can be seen from several factors, including trust and acceptance of the company, the willingness to achieve company goals and the desire to remain in the company.

These findings corroborate those of Khan \& Jaffar (2013), who discovered a favorable correlation between employee dedication and performance. These data suggest that organizational performance may be enhanced by employee commitment. This is also consistent with Fauzan (2015) study, which discovered that organizational commitment shown by workers of PT Bank Mandiri Tbk. Cirebon area (Yos Sudarso) has a favorable and substantial effect on employee performance at PT Bank Mandiri Tbk. Cirebon area (Yos Sudarso). According to the study, the size of the factors' impact on employee performance is 61.3 percent for the organizational commitment program performed at PT. Bank Mandiri Tbk. Cirebon region (Yos Sudarso). Meanwhile, the remaining 38.7 percent was impacted by unknown circumstances

\section{Conclusion}

The findings indicated that job insecurity characteristics and organizational commitment had an 
influence on the performance of nurses at the Makassar City Hospital's Inpatient Installation. The bivariate analysis results indicate that the job insecurity variable has an effect on the performance of nurses in Makassar City Hospital with a value of $p=0.0000 .05$, that the job insecurity variable has an effect on the organizational commitment of nurses in Makassar City Hospital with a value of $p=0.0000 .05$, and that the organizational commitment variable has an effect on the performance of nurses in Makassar City Hospital with a value of $p=0.0000 .05$. It is recommended that the hospital management pay attention to employees, better facilities and benefits, adequate working hours and rest, so that nurses feel at home working, providing allowances, providing opportunities to continue higher education levels, promotion, awarding exemplary nurses and participation in organizational policy making

\section{References}

Bosman, J., J.H. Buintendach, K Laba. (2005). Jon Insecurity, Burnout and Organizational Commitment AmongEmployees of AFinancial Institution in Gauteng. SA Journal of Industrial Psychology, 2005, 31 (4), 32-40.

Fauzan, A. H. (2015). Pengaruh Komitmen Organisasi Terhadap Kinerja Karyawan (Doctoral dissertation, Univesitas Pendidikan Indonesia).

Gasic, D., \& Pagon, M. (2004). Organisational commitment in the Slovenian police force. Policing in Central and Eastern Europe: Dilemmas of Contemporary Criminal Justice. University of Maribor. Slovenia.

Gaspersz, V. (2003). Manajemen Bisnis Total-Total Quality Management. Penerbit PT. Gramedia Pustaka Utama, Jakarta.

Gaunt, R., \& Benjamin, O. (2007). Job insecurity, stress and gender: The moderating role of gender ideology. Community, Work and Family, 10(3), 341-355.

Greenhalgh, L., \& Rosenblatt, Z. (1984). Job insecurity: Toward conceptual clarity. Academy of Management review, 9(3), 438-448.

Hadijah, H. (2016). Analisis Kualitas Pelayanan Rawat Inap di Rumah Sakit Umum Daerah Undata Palu Provinsi Sulawesi Tengah. Katalogis, 4(7).

Iman, Arief T. \& Lena, D. (2017). Bahan Ajar Rekam Medis dan Informasi Kesehatan (RMIK). Manajemen Mutu Informasi Kesehatan I: Quality Assurance. Pusat Pendidikan Sumber Daya Manusia Kesehatan Badan Pengembangan dan Pemberdayaan Sumber Daya Manusia Kesehatan, Kementerian Kesehatan RI. http://library1.nida.ac.th/termpaper6/sd/2554/19755.pdf

Kang, D. S., Gold, J., \& Kim, D. (2012). Responses to job insecurity: The impact on discretionary extra-role and impression management behaviors and the moderating role of employability. Career Development International.

Khan, F., \& Zafar, S. (2013). An empirical study of affective commitment across demographic groups in the banking sector of Pakistan. Pakistan Journal of Commerce and Social Sciences (PJCSS), 7(3), 555-563. 
Klandermans, B., Hesselink, J. K., \& Van Vuuren, T. (2010). Employment status and job insecurity: On the subjective appraisal of an objective status. Economic and Industrial Democracy, 31(4), 557-577.

Robbins, S. P., \& Judge, T. A. (2013). Organizational Behavior Edition 15 New Jersey.

Setiawan, R., \& Hadianto, B. (2008). Job insecurity dalam organisasi. Jurnal Manajemen Maranatha, 7(2), 69-79..

Silla, I., Gracia, F. J., Mañas, M. A., \& Peiró, J. M. (2010). Job insecurity and employees' attitudes: the moderating role of fairness. International Journal of Manpower..

Sopiah. (2008). Perilaku Organisasional. Yogyakarta: CV Andi Offset.

Sverke, M., Hellgren, J., \& Näswall, K. (2002). No security: A meta-analysis and review of job insecurity and its consequences. Journal of Occupational Health Psychology, 7(3), 242264. https://doi.org/10.1037/1076-8998.7.3.24

Tarigan, S.M. (2012). Job Insecurity ditinjau dari TingkatTrust Karyawan. VISI (2012) 20 (1):813823.

Yuwalliatin, S. (2006). Pengaruh Budaya Organisasi, Motivasi dan Komitmen Terhadap Kinerja Serta Pengaruhnya Terhadap Keunggulan Kompetitif Dosen Unissula Semarang. Jurnal Ekonomi Dan Bisnis, 7(2), 241-256. 